\title{
Sociopragmatic Description Of Narrative Movies And Their Communicative Intention
}

\author{
Mehriniso Kholmurodova, State Academy of Choreography of Uzbekistan
}

\begin{abstract}
The article deals with a communicative-pragmatic analysis of the participants in dialogue, facts, communication situation, conditions and linguistic integrity and their content. The degree of the elements of the systemic signals, the equilibrium between them, the communication are emphasized in the systemstructural approach. The choice of linguistic units, the reasons for assigning them to a particular communicative, emotional-expressive role, are seen. In the communication process, the pragmatic submission of participants is exposed through unique forms of arrangement of the general and universal laws of communication, in particular in film stories, through dialog between fact, the addressee and the addressee.
\end{abstract}

Keywords: sociopragmatics, communicative intention, speech act, pragmalinguistics, sociolinguistics, cognitive linguistics, speech tactics, reference, pragmatic competence, reference, presupposition

Received: 09.12.2020 Accepted: 11.01.2021 $\quad$ Published: 06.02.2021

\section{Introduction}

It is well established that linguistic factors play a specific role in the distinction of meanings of words in conjunction with communicative intentions. Ok, according to B. Menglev, a linguist who has conducted a special study on this subject, when a lexeme occurs in speech, the privatization of generality takes place on the basis of several intermediate steps. Morphological and syntactic levels coexist in the distinction and realization of these passages, which are considered intermediate lexical definitions, with different ratios of their "contributions". For example, a syntactic pattern incorporates a lexem into expression, while it is formed by a morphological tool. However, occasionally syntax and morphology predominate in the distinction between its intermediate lexical meanings. If syntax is capable of integrating lexem into speech and of separating its intermediate lexical meanings, morphology is restricted to its development. If the work of the syntactic pattern is limited to taking the unit into expression, the operation of the morphology will increase. He is now engaged not only in the development of lexem, but also in the distinction of intermediate syllables." Pragmatic meaning may exaggerate certain aspects of an individual without disclosing his or her personality, and in certain cases may serve the function of communicating the feelings of the communicator-the intention to influence. This, of course, calls for an acceptable realistic situation. Intention factor. Among other factors, the factor of intention also plays an important role in the expression of language units.

\section{Methods}

The type (level of transmission of information, exposure, transmission of information + exposure) and the level (such as strong intentions, weak intentions) of the purpose of the speaker predetermines the characteristics of the metaphorical meaning.

It is well recognized that the importance of metaphorical meaning is very poor because both the intention to inform and the urge to influence are not so high in communication. For example, neither knowledge nor influence is observed in the process of greetings, greetings, farewells. Just as it is a common practice, there is no straightforward answer to the question being posed, the speaker does not expect an answer to the question, the respondent is not obliged to give an accurate answer. This is decided by the weakness of the intentions:

The cup stuck in his throat and he began to speak:

- Zaynab granny, How are you holding up? Are you in a good mood? Are your bones still holding you up?

- Thanks god, grandfather, thank you for asking. How are you, are the kids growing up well?

- Thank you, shukran. But your voice is getting louder, is everything alright?

- What would happen bad but only peace, saint grandfather. Thank God my daughters have found their right place. These girls are making me get confronted with forbidden strangers. I've been sitting as like the day I died. (T.Murod, "No way to die in this world").

This dialog acts as a guide to the contact act of the communicators. The main objective of their contact is not expressed in this section. The words spoken act as a decoration for the scene to display the intent that 
is to be realized. In other terms, the words, combinations, and other expressions used in this passage can be evaluated as "hollow" language template resources.

Worldview factor. It is understood that the point of view and the level of the speaker also play an important role in the expression of the intention to speak. It is recognized that there is a definition of "Aesopian language" in science. The Greek counselor Aesop lived in the 6th century BC and had a very good intellect and worldview, even though he worked as a slave in the court of Croesus, King of Lydia. He created a lot of parabolas. The plot of almost all the parabolas produced in antiquity was considered to belong to Aesop.

Aesop's fables are written in a spirit of pessimism and desperation, characters are very conditioned, events are succinct, language is plain.

Ethical factor. Any speech is an act of morality, a representation of behavior. Therefore, when evaluating a person, it is necessary to pay attention to his speech, to observe his "sitting in circles." For example, hearing the speech of the immoral Homid ("Bygone days") exposes his identity from the first encounter: But as for me, I think he (Otabek is meant) forgot that he also had a wife in Margilan. (Abdulla Qodiriy "Bygone days"). In the conversation of Otabek and Kumush via letters, a high degree of spiritual purity is demonstrated in metaphorical expressions.

Text is a linearly ordered sign structure in which the polygonal structure of the denominator corresponds to the polygonal structure of the known denominator. The text serves as a symbol of the transformation of external speech into internal, internal speech into contemplation, and vice versa, internal thinking, internal speech into external speech. Each of these mechanisms has its own semantics, so the text's semantic structure contains three basic structures: the informational structure (external speech structure), the mental structure (internal speech structure) and the cognitive structure (thinking structure).

The object of speech can be defined by its denotative-predictive meaning. The speaker is responsible for the reasoning of building the context of the text. Listeners will understand the context of the text. Such a definition may be called axiological. Finally, the text produced acts as a representation of its meaning.

\section{Discussion}

The analysis of the socio-pragmatic features of the short stories "The apple of simple" and "The sacred stone" by the beloved Uzbek writer Erkin Azam will provide some insight into the expression of Uzbek language in literary texts in recent years. The writer incorporates a little chuckle at the norm stage in his work so as not to have a reader. In almost all of his works, the author uses light irony. In his film stories, he explains the hopes, objectives, goals and aspirations of the characters in words, using the power of language. Through his own voice, he will show the inner world, the history and the future of each hero. E.Azamov is able to articulate the intended picture through nouns, sentences, incomplete sentences. To clarify the point take an example of what we are looking for the basis for our opinion in the following text:

\section{"Summer night, not yet sunset .It was quite late.}

Breaking the silence, the phone rang, in a long line.

There was a school yard which borders of it joined woodland. Recess time. Screams echoed around the square:

- Fedka! Agile Fedka! Run !" (From "The sacred stone")

In the socio-pragmatic review of the film "Anoyi's Jaidari Apple" skilfully written by the poet, he works on specially selected texts. It explores the relationship between the speaker and the audience, the author and the addressee. We will try to decide the socio-pragmatic character of the following text: "Two days before the trial, wearing the medals he had won in the war on his scented suit Ramazan's father and brother who was driver a state farm, arrived there.

The father repeats the same thing to the man he saw:

- He runs away from the wedding with first possible attempt. It seems he doesn't like his cousin's daughter, as whenever you open the theme about the wedding - he flees away Tashkent under the pretext of studying. This has been the case since he returned from the Army. Her mother is lying on her bed in a critical condition, screaming, "I'm leaving without seeing my son's happiest day." Llook at this case of a man who can't swallow sweet in his mouth now!"

There is no need for descriptions of the protagonist's social standing, thought, worldview. Every hero knows, through his voice, who he is, his social standing in society. It is clear from the content of the conversation that Ramazan's father uses dialect words in his voice, which are an aspect of living language, and that Uzbek and old traditions are related to the dream of the parents. The author uses the word "squeaky squeaky" in the father's language to specifically explain the state of the mother to the addressee. This is the situation of a mother who is expecting and worried about her son. 
Communication is the result of a human-thinking activity in which speech-holders construct colorful speech structures (speech acts) aimed at various objectives. Speech Act is a goal-oriented speech activity that is approved by members of the society and carried out in compliance with the rules of speech conduct. The theory of speech was first put forward by the English philosopher J. It's Austin. The authors of speech act theory are J. Austin, J. Serl, J.; According to the Russians, an elementary speech activity, articulated on the basis of language rules and expressing a certain substance, is a speech actIn particular, in the speech act, J.Austin states that the following takes place: the pronunciation of specific sounds belonging to a commonly accepted language code; the composition of sentences based on grammatical rules from words belonging to that language; the provision of sentences with material, references, etc.; the development of speech applications and coordination with reality; the directing of speech expressions to a specific language; According to TV Jerebillo, a speech act is a psychophysical mechanism that represents the relation between the speaker (the addresser) and the listener (addressee) and consists of the following components: 1) speaking (writing); 2) perception; 3) comprehension of speech (context). According to M. Hakimov, the definition of a speech act is a statement of the relationship between actions of reciprocal significance that takes place in the process of communication between people. It is evident from the meanings that a speech act takes place within the context of speech communication, that it is established in relation to the speech participants, the situation of speech, the general knowledge of the language owners on the subject of speech, the knowledge of the language and the skills of the speech participants. M. Hakimov notes that in general, the following components are involved in the speech act: the speaker, the listener, the object of speech is the factual material and the speech situation. M. Kurbanova points out that the general language knowledge and language skills of the participants should be included in the list of components required for the application of the speech act. Indeed, if the participants in the speech may not have a general knowledge of the language, the speech act would not only be incomprehensible to the parties, but it is impossible to take place. Since a speech act is subject to a particular communicative intent of the speaker, the various embodiments of the act differ. Thus, in their speech practices in the text of the film plot, they make good use of overt and indirect modes of purposeful speech. In the forms of indirect speech actions used in their speech, the following two separate cases are observed: (a) the primary sense of the syntactic structure is maintained, to which an additional syntactic meaning is assigned. In other words, the information and additional information unique to its representation are conveyed via the same syntactic structure. This extends the semantic scope of the same syntactic structure; b) the original sense of the syntactic structure is totally lost, substituted by another syntactic meaning. In other words, other scientific knowledge is conveyed in relation to the intent of the speaker by means of the same syntactic structure: "The stubbornness of the stubborn borther worsens:

- You have caressed your son, father! You should have made him to marry, even if he was handcuffed. What can be that he can lack as he is making us so ashamed!

The father had stood up and started complaining to me:

- Oh, nephew, you re highly educated person, you are smarter, you could have turned your friend away from his notorious mind! What a disaster..." In this situation of speech, the addresser communicates to the addressee an act of notice that he is unhappy with it and a reprimand that may dissuade his son from doing so.

Throughout the novel, the speaker asks questions that determine the nature of behavior, clarify the topic: "-Defendant Haydarov Ramazan, have you been involved in this case before? - asked the judge.

- I, Haydarov Ramazan, was born in 1950 in the Boysun district. Then... - stammering was stopped by the judge.

- Defendant Haydarov, no one is asking you for your date of birth. Have you been speculating before?

- Then I graduated from high school and served in the Soviet Army . After that..." In this speech act, the addressee provides irrelevant answers to the confusing topic of the important questions posed by the addressee. This is a phenomenon that depends on the situation of speech. It is clear that the social climate and the conditions for expression pressured Ramazan to provide such information.

Another peculiarity of film stories is that truth is exposed primarily by dialog between the addressee and the addressee:

"-Look, Haydarov, you were caught with three suitcases and two boxes, weren't you? Whose were the rest?

- So they belonged to someone else. Sensing that the security officers were watching, he threw things at you and ran away, right? Huh, Haydarov?

- That's right ... Eh, no, it was mine, mine!

- Defendant Haydarov! Remember. Or don't you have a fever? Tell me what's the matter with you, we could stop the trial. 
-Oh, why? i am very healthy..." Although the addressee clearly understands the questions posed by the speaker, he does not respond logically to them. It is clear from the substance of this speech act that Ramadan does not want to say anything, he wants to protect others and take the blame.

The speaker attempts to discover the logic himself by asking the addressee clearer questions in order to find out his purpose:

"-So tell me, where were you going with so many grapes and pomegranates? For what purpose?

-Just to get around. Barnaul is a place of my army service. Great place, a lot of my brothers are there.

-Do you take so much to your brothers?

-No, I only got four apples for them. Not to be ashamed with empty hands.

-What about grapes and pomegranates? You wanted to sell them, didn't you?

-Why should I sell? After all, they ... You know, I went to Barnaul ...

-Hey, Barnaul, Barnaul! Where did you get the apple?

-What do you mean from where? That's clear just from our garden. Visit there in the fall, our garden is overflowing, spilling on the ground."

At this point, the addressee often asked numerous questions in order to gain details on the actions of the listener-defender. The last reply of the addressee clarifies those details about him. Yet questions are also being asked to the listener over and over again. Before the speaker gets the details he wants, the following loopy questions were asked:

- Did you have to bring an apple from there? As a gift, could you get it from Tashkent?

"The apples of this places are not enough tasty as ours. They are bitter, scenting the taste of the drug. We have an apple like that, Boysun's apple, we call it a "local apple. Elsewhere, it doesn't mature but only there. It's ugly, but it's so sweet, so sweet, if you taste it, you will ..."

While this speech act reflects the simplicity of the complainant, the judge is not involved in the meaningful definition of Ramadan offered to the local apple .

In a speech scenario, the speaker must pick words and deliver a speech. Although the trial is a formal speech occurrence, the speaking judge brings the defendant closer to him and talks from his psyche's social climate. However, the conditions of expression do not follow the criteria of the situation:

"- Brother, you know, we want to help you. Think carefully and tell the truth. Your destiny is being decided, after all!

- Dear sister, forgive me once!

- I am not "dear sister" to you!

- You call yourself "brother", then how can I call you? If I don't know your name, I don't know your last name...

- You don't have to know my name. I am a civil judge for you!

- I am also a civil resident.

- No, you are now - the accused, the guilty!

"Am I ... guilty ?!" I'm sorry, I'm guilty..." It turned out that the speaker was the addressee, that is, the judge addressed the addressee as a "brother" but the defendant also replied to her in the same tone, an odd circumstance for the speaker and a situation of speech. The condition, quality and value of the communication are also directly linked to the situation of speech.

In film stories, various types of expression are used. Especially from internal monologues. Erkin A'zam also uses these monologs in his films to expose the psychology of the protagonists: "It has been five months since Ramazan's imprisonment. For five months, whether I walk or stand, there is a knot inside me, a hard, painful knot. My soul comes out, I curse Ramazan, I curse, I wonder, I want to see it, I miss him! I feel guilty in front of him. True, he offended me a lot, left me in a lot of trouble; maybe a slanderer, a spy, but still - my friend! My buddy is lying down. He is in prison. What kind of place is it?" this speech act in the form of a message detail experience reveals the human image of the speaker. This shows that Ramazan is a precious person (although it is not written).

Anyone who reads Erkin Azam's work on any genre of film will have a real image in front of his eyes. In particular, in the work "The sacred stone".

In this film, there is a speech situation in which the speaker pleads with his listener: aunty (recognizing his former student). Ziyodullaev, is it you? Could that remain still ...

“-Marjon

-Ziyodullaev (coming closer with a smile). We have a deal, Marina Grigorevna. If our deal is already ripe! If you say now, I will bring your money now!

Aunty Marjon: - What kind of rush are you doing, Shaydulla? Or do you want me to leave soon?

Shaydulla: Oh, no, no! You have educated me, that's not polite until my blindness."

It is also evident from the contact that the addressee makes a request to the addressee in the form of a request. The addressee, on the other hand, is trying to justify the situation even though the purchaser cannot dispute his word, taking into account that he was once a tutor. 
The inner world of the speaker and the listener is exposed one after the other in the next sections of the conversation. The student acknowledges that the letter has been taught, but is unable to show its realistic expression. In this case, the instructor remembers what he said earlier. In short, she called him to be honest:

"Shaydulla (coldly): - I am a state person, Marina Grigorevna, my time is short! I'll break it down today if you'll let me.

Marjon aunty: - What are you trying to break?You said you will open a shop, didn't you?

Shaydulla: - Is it possible to open a shop without breaking the street wall ?!

Marjon aunty: - That's my house and I am sheltering it now.Muslim! I'm still alive!

Shaydulla: Stay alive and live.But on the second floor. Then you sell it to me anyway! I promised the mayor I had to open the store before the Independence Day!"

Erkin Azam's film "Scrubby valentine" is also one of the most artistic and esthetically appealing works of art. In analyzing the text of the novel, along with the events in it, the peculiarities of the protagonists are vividly represented in the form of a dialogue: "Dadil(laughs): You're agile. The truth is, there is no cure for it, and nothing is of any use. For example, I didn't have any knowledge or practice: I took a syringe, took a handful of vitamins, hung on a horizontal bar, ate carrots ... You can see for yourself whether it worked or not! Put it this way, What is you height? You must be one hundred and fifty.

Shamshod:- One hundred and fifty one!

Dadil:- Are you cheating? (Pointing to Shamshad's shoes) Probably at the expense of the shoes` heel?

Shamshod: Taking into account that add to that one hundred and fifty-five." It is also evident from the name of the work that the key problem relates to height. The shortness of the neck is the major issue for both the speaker and the audience. Both the addressee and the addressee correspond to the speech situation in the sense of the actual act message in this letter. And in short sentences, what they want to say to each other will be obvious. If the addressee in that text interacts with someone other than his or her listener on the same subject, more time and more vocabulary would be needed for both parties to understand each other. Here, too, the question of the context of speech or spiritual closeness to the subject remains important: Dadil (with humor). Yes, if you try again, you will become a basketball player! .. Yes, why are you silent? Don't worry, brother, that's not all! Look, I'm forty-nine, and I'm not dead! (Pointing to a guy standing on the edge of the station.) Look at that guy! God did not give up and give wisdom! It's all gone ... Look at it now. (Looking at the tall guy) Hey lanky, come here!

Lanky (surprised): Me?

\section{CONCLUSION}

It is likely that the addressee will become the addressee at the same time, and vice versa, in such a case the addressee-the speaker, while the other person remains the addressee-will become the listener, even though he speaks. In the play, who handles the circumstance of a bold speech by his own name, he can turn the subject in any direction and ask his interlocutor for his attitude to what he says. The addressee is the Shamshad listener. His views on the subject of discussion are not very important to the speaker, he just takes them as facts, but he encourages the speaker to express every idea he says. In Erkin Azam's stories, the problem of the social specialization of language was analyzed in a certain way. The author has been able to make good use of all the linguistic possibilities of the language. Also, in film stories, only verbal means are missing to vividly represent the two and the external world of the addressee and the addressee, and the performance of works in this genre also includes the use of non-verbal means. Since life is an integral and continuous structure, its language form must have the same essence. In doing so, thought is the link that coordinates these two beings, balancing their interrelated relationships.

\section{References:}

1. Galperin I. R. Text as an object of linguistic research / I. R. Galperin. - M.: Nauka, 1981.-139 p.

2. Bolotnova NS Tasks and main directions of communicative stylistics of artistic text / NS Bolotnova // Bulletin of Tomsk. state ped. un-that. Ser .: Humanities. - Issue. No. 6. - Tomsk, 1998. - pp. 72-93.

3. Kolshansky GV Communicative function and structure of language / GV Kolshansky. - M.: Nauka, 1984 .- 175 p.

4. Dyck van TA The strategy of understanding the associated text / TA van Dyck, V. Kinch // New in foreign linguistics. Cognitive aspects of language. - Issue. XXIII.

- M.: Progress, 1988. - S. 153-206.

5. Protasova E.Yu. Functional pragmatics: a variant of sociolinguistics or a general theory of linguistics? // Questions of linguistics, 1991, № 1.

6. Rakhimov S. Speech communication and the problem of deixis in multi-system languages. - T.: Fan, 1989. - 119 p. 
7. Safarov Sh., Shishkina TA On the conditions for the implementation of the principle of politeness in text-forming actions // Logical-semantic and pragmatic problems of the text.- Krasnoyarsk: KSPI, 1990.P.63-69.

8. Safarov Sh., Shishkina T.A. Communicative and pragmatic functions of exclamation in dialogue // Thinking and communication. - M .: Institute of Linguistics, 1990. - S. 126-132.

9. Safarov Sh. Ethnocultural components of discursive activity // Language, Discourse and Personality. Tver, 1990. - S. 105-111.

10. Saussure de F. Course of General Linguistics. - M .: URSS, 2004.256 p.

11. Stepanov Yu.S. Alternative world, discourse, fact and principles of causality // Language and science of the end of the XX century.- M., 1995.-C.35-73.

12. Searle J. Classification of illocutionary acts. In the book: New in foreign linguistics. Issue 17. The theory of speech acts. M .: Progress, 1986. -S. 170-194.

13. Stephenson Ch. Some pragmatic aspects of meaning. In the book: New in foreign linguistics. Issue 16, Linguistic pragmatics), Moscow: Progress, 1985, pp. 129-154.

14. Susov I.P. Semiotics and linguistic pragmatics. In the book: Language, discourse and personality. Tver: Publishing house of Tverskoy University, 1990. - S. 125-133.

15 Toirova G. About the technological process of creating a national corps. // Foreign languages in Uzbekistan. Electronic scientific-methodical journal. - Tashkent. 2020, № 2 (31), -B.57- 64. https://journal.fledu.uz/uz/ 2-31-2020

16 Toirova G. The Role of Setting in Linguistic Modeling.International Multilingual Journal of Science and Technology. ISSN: 2528-9810 Vol. Issue 9, September - 2019, -P.722-723 https://www.ijrte.org/wpcontent/uploads/papers/v8i2S10/B10570982S1019.pdf

17 Adams J.K. Pragmatics and Fiction - Amsterdam: J.Benjamins Publishing Comp., 1985. - 77 p.

18 Bach K., Harnish R.M. Linguistic communication and speech acts. - Cambridge, Mass.: MIT Press, 2000, $-484 \mathrm{p}$. 